\title{
Science and islands in Indo-Pacific worlds
}

\author{
SEBESTIAN KROUPA*, STEPHANIE J. MAWSON*" AND \\ DORIT BRIXIUS *** (GUEST EDITORS)
}

\begin{abstract}
This Introduction offers a conceptualization of the Indo-Pacific, its islands and their place within the history of science. We argue that Indo-Pacific islands present a remarkable combination of social, political and spatial circumstances, which speak to themes that are central to the history of science. Having driven movements of people and represented staging grounds for explorations, expansions and cross-cultural exchanges, these spaces have been at the forefront of historical change. The historiographies of the two oceans have traditionally emphasized indigenous agency while downplaying European historical trajectories, and therefore they provide historians of science with materials and methodologies that promise nuanced portrayals of knowledge production in cross-cultural settings. Rather than unifying the oceans into a cohesive narrative, we seek to uncover the many horizons of Indo-Pacific worlds and pluralize the spaces within which knowledge travelled at specific times, but not at others. Offering a middle plane between the globe and the region, islands are particularly productive sites for such analyses, as they bring to attention both localized kinds of agency and the impacts of colonialism and globalization. This special issue investigates what happens to knowledge within island spaces and demonstrates that even as small strips of land, islands can significantly enhance our understanding of the practices of knowledge making within the broader contours of world history. In bringing to the fore the contributions of actors from across the wider social spectrum and, especially, the interacting roles of indigenous agents and their traditions, Indo-Pacific worlds thus offer exciting new directions for a field which has often been dominated by a focus on European institutions.
\end{abstract}

When the world first began there was no land, but only the sea and the sky, and between them was a kite. One day the bird which had nowhere to light grew tired of flying about, so she stirred up the sea until it threw its waters against the sky. The sky, in order to restrain the sea, showered upon it many islands until it could no longer rise, but ran back and forth. Then the sky ordered the kite to light on one of the islands to build her nest, and to leave the sea and the sky in peace. ${ }^{1}$

* Department of History and Philosophy of Science, University of Cambridge. Email: sk796@cam.ac.uk.

* Faculty of History, University of Cambridge. Email: sjm277@cam.ac.uk.

*** Institut historique allemand Paris. Email: dbrixius@dhi-paris.fr.

We owe debts of gratitude to the British Society for the History of Science for their generous support and sponsorship of the organization of the Science and Islands in the Indo-Pacific World conference (Cambridge, 15-16 September 2016), out of which this special issue grew. We would like to thank the conference participants and guest speakers whose formal and informal contributions were critical to the thinking reflected in this essay and issue. In addition, this paper benefited greatly from discussions with Nick Jardine, Simon Schaffer, Jim Secord, Sujit Sivasundaram, Jenny Bulstrode, Megan Barford, Karol Florek and the participants of the Global Histories reading group in Cambridge. We also thank two anonymous reviewers for their helpful feedback. For generously providing the spaces where the conference took place, we thank the Department of History and Philosophy of Science in Cambridge.

1 'The creation story', in Mabel Cook Cole, Philippine Folk Tales, Chicago: A.C. McClurg \& Co., 1916, pp. 187-188, 187. 
This Philippine origin myth, first recorded in European sources in the sixteenth century, reflects the centrality of islands to the cosmology of the inhabitants of the Philippine archipelago. ${ }^{2}$ While the sea and the sky are constants, islands are the origin of human life. Their physicality features heavily within religious traditions, wherein the environment is heavily imbued with spiritual meaning that enabled Philippine islanders to make sense of their world. ${ }^{3}$ Islands are likewise important within Pacific genealogies, not least because they are the centre of one of the greatest migration stories in human history: the peopling of the Pacific Ocean, which began more than three thousand years ago, long before the first presence of Europeans in that oceanic space. ${ }^{4}$ For voyagers who crossed oceanic spaces, islands offered both respite - as sites for replenishing victuals - and danger, where many a ship was wrecked on unseen reefs or shoals. At the same time, islands were staging grounds for expansion and strategic posts safeguarding trade routes and territories.

For millennia, islands in the Indo-Pacific have been at the forefront of historical change. They have represented waypoints for travellers and explorers; cross-cultural meeting points and melting pots; garrison states and units of organization and power; laboratories of scientific, social and colonial practices; foci of Edenic fantasies; as well as places of social repression and control, of exile and penal incarceration. Islands thus evoke - often simultaneously - the notions of freedom and captivity, paradise and inhospitality, wealth and penury, isolation and connection. They are multifaceted entities, with their metaphorical constructions reflecting their role as significant sites of historical events. Mediating flows of people, objects and ideas across vast spaces, islands are historically contested areas, which have proved important for trade, navigation and human imagination. Islands prove a valuable analytical category precisely because they can be explored from so many points of view.

This special issue explores the islands of the Indo-Pacific from the perspective of the history of science. It had its genesis in a conference which took place at the University

2 This myth was first recorded by the anonymous author of the Boxer Codex, and was repeated through the centuries before being collected in the above citation by the American folklorist Mable Cook Cole in 1916. See Boxer Codex, The Lilly Library Digital Collections, at www.indiana.edu/ liblilly/digital/collections/items/ show/93, ff. 28r-28v, accessed 6 September 2018. For a recent transcription and translation of the original manuscript see George Bryan Souza and Jeffrey S. Turley (eds.), The Boxer Codex: Transcription and Translation of an Illustrated Late Sixteenth-Century Spanish Manuscript Concerning the Geography, Ethnography and History of the Pacific, South-East Asia and East Asia, Leiden: Brill, 2016, pp. 53-54, 336-337.

3 Mark Dizon, 'Sumpong spirit beliefs, murder, and religious change among eighteenth-century Aeta and Ilongot in eastern central Luzon', Philippine Studies (2015) 63, pp. 3-38; Dizon, 'Social and spiritual kinship in early-eighteenth-century missions on the Caraballo mountains', Philippine Studies (2011) 59, pp. 367-398; Alfred McCoy, 'Baylan, animist religion and Philippine peasant ideology', Philippine Quarterly of Culture and Society (1982) 10, pp. 141-194. Similar belief systems are also evident in other parts of Southeast Asia. See Henri Chambert-Loir and Anthony Reid, The Potent Dead: Ancestors, Saints and Heroes in Contemporary Indonesia, Honolulu: University of Hawaii Press, 2002; Barbara Watson Andaya, 'Rivers, oceans, and spirits: water cosmologies, gender, and religious change in Southeast Asia', TRaNS: Trans-regional and -national Studies of Southeast Asia (2016) 4, pp. 239-263. Andaya, 'Seas, oceans and cosmologies in Southeast Asia', Journal of Southeast Asian Studies (2017) 48, pp. 349-371.

4 Matt K. Matsuda, Pacific Worlds: A History of Seas, Peoples, and Cultures, Cambridge: Cambridge University Press, 2012, pp. 9-36. 
of Cambridge in September 2016, generously sponsored by the British Society for the History of Science. Here we offer a selection of papers drawn from this event and ongoing discussions. At this critical moment in the emergence of 'island studies' as a new area of research, we seek to use the special nature of islands to investigate how these spaces have shaped practices of knowledge construction and communication. ${ }^{5}$ By knowledge, we understand both a cross-cultural diversity of beliefs about the workings of the universe and the command of a myriad of techniques applied to investigations and manipulations of worldly phenomena. Since islands can exemplify a multiplicity of functions and dimensions, they allow for a dynamic understanding of the spectrum of agents and agendas involved in knowledge production and mobilization in cross-cultural settings. This special issue seeks to contribute especially to studies concerned with these processes. ${ }^{6}$ Even as small stretches of land, islands hold the power to recontextualize structures of empire and practices of knowledge making within the broader contours of world history.

The decision to focus on the Indo-Pacific is also important. While we by no means conceptualize these distinct oceans as a connected world in a Braudelian sense, ${ }^{7}$ we do argue that the Indo-Pacific offers historians of science the opportunity to expand their methodological horizons. The historiographies of both these oceans de-emphasize European historical trajectories while emphasizing indigenous agency and knowledge. Such traditions offer exciting new directions for a field which has often been overly focused on European knowledge systems and scientific methods. As many of our contributors demonstrate, pluralizing the concept of knowledge production and seeking out the 'middle grounds' of cultural exchange dramatically shift our perspectives on the history of science. ${ }^{8}$ Moreover, by conceptualizing the Indo-Pacific as an analytical

5 Rod Edmond and Vanessa Smith (eds.), Islands in History and Representation, London and New York: Routledge, 2003; Godfrey Baldacchino (ed.), A World of Islands, Charlottetown: University of Prince Edward Island, 2007; John R. Gillis and David Lowenthal (eds.), Islands, special issue of Geographical Review (2007) 97; Elizabeth Deloughrey (ed.), The Literature of Postcolonial Islands, special issue of New Literatures Review, 2011; Elizabeth MacMahon, Carol Farbotko, Godfrey Baldacchino, Andrew Harwood and Elaine Stratford, 'Envisioning the archipelago', Island Studies Journal (2011) 6, pp. 113-130; Leida Fernández Prieto, 'Islands of knowledge: science and agriculture in the history of Latin America and the Caribbean', Isis (2013) 104, pp. 788-797; Antonis Hadjikyriacou (ed.), Insularity in the Ottoman World, special issue of Interdisciplinary Journal of Middle Eastern Studies (2017) 18. See also the various issues of Island Studies Journal.

6 Christopher A. Bayly, Empire and Information: Intelligence Gathering and Social Communication in India, 1780-1870, Cambridge: Cambridge University Press, 1999; David N. Livingstone, Putting Science in Its Place: Geographies of Scientific Knowledge, London and Chicago: The University of Chicago Press, 2003; James A. Secord, 'Knowledge in transit', Isis (2004) 95, pp. 654-672; Kapil Raj, Relocating Modern Science: Circulation and the Construction of Knowledge in South Asia and Europe, 1650-1900, Basingstoke: Palgrave Macmillan, 2007; Lissa Roberts, 'Situating science in global history: local exchanges and networks of circulation', Itinerario (2009) 33, pp. 9-30; Simon Schaffer, Lissa Roberts, Kapil Raj and James Delbourgo (eds.), The Brokered World: Go-Betweens and Global Intelligence, 1770-1820, Sagamore Beach, MA: Science History Publications, 2009; Sujit Sivasundaram, 'Sciences and the global: on methods, questions, and theory', Isis (2010) 101, pp. 146-158.

7 Fernand Braudel, The Mediterranean and the Mediterranean World in the Age of Philip II, vol. 1 (trans. Siân Reynolds), Berkeley, CA: University of California Press, 1995.

8 The term 'middle ground' comes from Richard White, The Middle Ground: Indians, Empires, and Republics in the Great Lakes Region, 1650-1815, Cambridge: Cambridge University Press, 1991. 
tool, rather than as a bounded, interconnected world, we propose that new comparisons can be made between places that have traditionally been seen as disconnected. Indeed, Indo-Pacific histories were less circumscribed by national, imperial or linguistic barriers than was once assumed and divisions along such lines fail to capture the dynamics of this universe. ${ }^{9}$ The aim of this issue is thus to present Indo-Pacific islands as sites of global microhistories, which illustrate the ways in which cross-cultural interactions generated scientific and cultural knowledge production. ${ }^{10}$

\section{Finding the Indo-Pacific}

Ever since Fernand Braudel conceptualized the Mediterranean as a distinct world of social, cultural and intellectual circulations, historians have sought to reorient our understanding of history away from national borders and towards the study of regional connections and interactions, particularly those that circulated around seas and oceans. ${ }^{11}$ The most prolific of these new transoceanic approaches is Atlantic history; ${ }^{12}$ however, historians have also begun to posit distinct regional histories of Indian and Pacific Ocean worlds. ${ }^{13}$ Like the Atlantic, both the Indian and the Pacific Oceans have

9 See, for example, Leonard Y. Andaya, The World of the Maluku: Eastern Indonesia in the Early Modern Period, Honolulu: University of Hawaii Press, 1993; Andaya, 'Local trade networks in Maluku in the 16th, 17th, and 18th centuries', Cakalele: Maluku Research Journal (1991) 2, pp. 71-96; Romain Bertrand, 'Spirited transactions: the morals and materialities of trade contacts between the Dutch, the British and the Malays (1596-1619)', in Maxine Berg (ed.), Goods from the East, 1600-1800: Trading Eurasia, Basingstoke and New York: Palgrave Macmillan, 2015, pp. 45-60; Sebestian Kroupa, 'Ex Epistulis Philippinensibus: Georg Joseph Kamel SJ (1661-1706) and his correspondence network', Centaurus (2015) 57, pp. 229-259.

10 For global microhistories see especially Francesca Trivellato, 'Is there a future for Italian microhistory in the age of global history?', California Italian Studies (2011) 2, n.p.; Jacques Revel (ed.), Jeux d'échelles: La micro-analyse à l'expérience, Paris: Seuil, 1996.

11 Braudel, op. cit. (7); David Armitage, Alison Bashford and Sujit Sivasundaram (eds.), Oceanic Histories, Cambridge: Cambridge University Press, 2017; Jerry H. Bentley, 'Sea and ocean basins as frameworks of historical analysis', Geographical Review (1999) 89, pp. 218-224; Philip E. Steinberg, The Social Construction of the Ocean, Cambridge: Cambridge University Press, 2001; Peter N. Miller (ed.), The Sea: Thalassography and Historiography, Ann Arbor: University of Michigan Press, 2013; Rila Mukherjee, 'Escape from terracentrism: writing a water history', Indian Historical Review (2014) 41, pp. 87-101.

12 For example, Bernard Bailyn, Atlantic History: Concept and Contours, Cambridge, MA: Harvard University Press, 2005; Alison Games, 'Atlantic history: definitions, challenges, and opportunities', American Historical Review (2006) 111, pp. 741-757.

13 For a recent synthesis of oceanic historiography see Armitage, Bashford and Sivasundaram, op. cit. (11). On the Indian Ocean see Kirti N. Chaudhuri, Trade and Civilisation in the Indian Ocean: An Economic History from the Rise of Islam to 1750, Cambridge: Cambridge University Press, 1985; Michael N. Pearson, The Indian Ocean, London: Routledge, 2003; Sugata Bose, A Hundred Horizons: The Indian Ocean in the Age of Global Empire, Cambridge, MA: Harvard University Press, 2006; Engseng Ho, The Graves of Tarim: Genealogy and Mobility across the Indian Ocean, Berkeley: University of California Press, 2006; Isabel Hofmeyr, 'The complicating sea: the Indian Ocean as method', Comparative Studies of South Asia, Africa and the Middle East (2012) 32, pp. 584-590; Antoinette Burton, Madhavi Kale, Isabel Hofmeyr, Clare Anderson, Christopher J. Lee and Nile Green, 'Sea tracks and trails: Indian Ocean worlds as method', History Compass (2013) 11, pp. 497-502; Abdul Sheriff and Engseng Ho (eds.), The Indian Ocean: Oceanic Connections and the Creation of New Societies, London: Hurst \& Company, 2014; Markus P.M. Vink, 'Indian Ocean studies and the "New Thalassology"', Journal of Global History (2007) 
played important roles in the development of global history, facilitating the flow of commodities, people, ideas, cultures and languages across vast spaces. ${ }^{14}$ This special issue demonstrates that the study of these discrete, yet connected, oceanic worlds offers a great deal to global historians and historians of science. While we recognize the distinct nature and histories of these two oceanic spaces, the Indo-Pacific presents an opportunity to adopt new methodologies that emphasize cross-cultural exchange, while taking nonEuropean knowledge systems as seriously as their European counterparts. To illustrate this point, this section begins with a historiography of oceanic worlds, which we use as a basis for explaining what distinguishes the Indo-Pacific from its Atlantic counterpart.

Half a century after Braudel wrote his pioneering works on the Mediterranean, the field of Atlantic history exploded on the academic stage in a dramatic fashion, generating a plethora of books, articles, $\mathrm{PhDs}$, university courses and academic positions. ${ }^{15}$ Conceptualization of the Atlantic as a world interconnected by oceanic currents offered historians exciting possibilities to study the flow of not just goods and people, but also cultures and ideas between Europe, Africa and America. Despite this, the original framework of Atlantic history was inherently conservative. ${ }^{16}$ The leading theorist of the field, Bernard Bailyn, traced the idea of a connected Atlantic world back to the post-war period in which the North Atlantic Treaty Organization was formed, wherein both sides of the Atlantic were attracted to the alluring notion of a shared

2, pp. 41-62; Edward A. Alpers, The Indian Ocean in World History, Oxford: Oxford University Press, 2014. On the Pacific Ocean see Oskar H.K. Spate, The Pacific since Magellan, 3 vols., Canberra: Australian National University Press, 1979-1988; Matsuda, op. cit. (4); Matt Matsuda, 'The Pacific', American Historical Review (2006) 111, pp. 758-780; Paul D'Arcy, The People of the Sea: Environment, Identity, and History in Oceania, Honolulu: University of Hawaii Press, 2006; Margaret Jolly, 'Imagining Oceania: indigenous and foreign representations of a sea of islands', Contemporary Pacific (2007) 19, pp. 508-545; Nicholas Thomas, Islanders: The Pacific in an Age of Empire, New Haven: Yale University Press, 2010; David Armitage and Alison Bashford (eds.), Pacific Histories: Ocean, Land, People, New York: Palgrave Macmillan, 2014.

14 For the Manila galleon and Chinese trade see William Lytle Schurz, The Manila Galleon, New York: E.P. Dutton \& Co., 1959; Denis O. Flynn and Antonio Giráldez, 'China and the Manila galleons', in A.J.H. Latham and Heita Kawakatsu (eds.), Japanese Industrialization and the Asian Economy, London: Routledge, 1994, pp. 71-90; Flynn and Giráldez, 'Silk for silver: Manila-Macao trade in the 17th century', Philippine Studies (1996) 44, pp. 52-68; Flynn and Giráldez, 'China and the Spanish Empire', Journal of Iberian and Latin American Economic History (1996) 14, pp. 309-338; Katharine Bjork, 'The link that kept the Philippines Spanish: Mexican merchant interests and the Manila trade, 1571-1815', Journal of World History (1998) 9, pp. 25-50; Antonio Giráldez and Denis O. Flynn, 'Cycles of silver: global economic unity through the mid-eighteenth century’, Journal of World History (2002) 13, pp. 391-427. For an overview of the spice trade and European rivalry over the Indian Ocean trade routes see Carla Rahn Phillips, 'The growth and composition of trade in the Iberian empires, 1450-1750', in James D. Tracy (ed.), The Rise of Merchant Empires: Long-Distance Trade in the Early Modern World, 1350-1750, Cambridge: Cambridge University Press, 1990, pp. 34-101; Paul Freedman, Out of the East: Spices and the Medieval Imagination, New Haven, CT: Yale University Press, 2008.

15 Michael A. McDonnell, 'Paths not yet taken, voices not yet heard: rethinking Atlantic history', in Anny Curthoys and Marilyn Lake (eds.), Connected Worlds: History in Transnational Perspective, Canberra: ANU Press, 2005, pp. 46-62, 46. See, for example, Bailyn, op. cit. (12); David Armitage, 'Three concepts of Atlantic history', in David Armitage and Michael J. Braddick (eds.), The British Atlantic World, 1500-1800, Basingstoke: Palgrave Macmillan, 2002, pp. 11-27; Jorge Cañizares-Esguerra and Erik R. Seeman (eds.), The Atlantic in Global History, 1500-2000, New York: Routledge, 2017.

16 Armitage, Bashford and Sivasundaram, op. cit. (11), pp. 13-14. 
'civilization' that connected European and North American societies. ${ }^{17}$ As David Armitage has argued, this genealogy of Atlantic history lends itself predominantly to the history of the northern Atlantic and to the birth of a (largely white) Western civilization, lauding the triumph of capitalism and Western liberal democracy while ignoring non-white and non-elite subjects. ${ }^{18}$ In response, studies of the 'black' and 'red' Atlantics have resurrected histories of the slave trade and emphasized the contribution of non-European figures and a 'motley crew' of sailors, pirates, labourers and indentured servants. ${ }^{19}$ Similarly motivated, the recent emergence of Iberian and Arctic Atlantic histories has brought pioneering insights with respect to approaches to non-European agency. ${ }^{20}$ Despite these efforts, the 'North Western' trope remains powerful, alongside an emphasis on the domination of empire within people's everyday lives. ${ }^{21}$ Even though non-Westerners increasingly feature as mediators and participants in historical narratives, the focus often fails to move beyond European impacts on 'others'. Combined with the periodization of the field - which begins with European conquests of the Americas - this has led some historians to question whether Atlantic history 'is

17 Bailyn, op. cit. (12).

18 Armitage, Bashford and Sivasundaram, op. cit. (11), p. 14.

19 For example, James Delbourgo and Nicholas Dew (eds.), Science and Empire in the Atlantic World, New York: Routledge, 2008; Neil Safier (ed.), Itineraries of Atlantic Science: New Questions, New Approaches, New Directions, special issue of Atlantic Studies (2010) 7; Daniela Bleichmar and Peter Mancall (eds.), Collecting across Cultures: Material Exchanges in the Early Modern Atlantic World, Philadelphia: University of Pennsylvania Press, 2011; Pablo F. Gómez, The Experiential Caribbean: Creating Knowledge and Healing in the Early Modern Atlantic, Chapel Hill: University of North Carolina Press, 2017. For the 'black' Atlantic see, for example, John Thornton, Africa and Africans in the Making of the Atlantic World, 1400-1800, Cambridge: Cambridge University Press, 1998; David Eltis, The Rise of African Slavery in the Americas, Cambridge: Cambridge University Press, 2000; Judith Ann Carney, Black Rice: The African Origins of Rice Cultivation in the Americas, Cambridge, MA: Harvard University Press, 2009; David Lambert, Mastering the Niger: James MacQueen's African Geography and the Struggle over Atlantic Slavery, Chicago and London: The University of Chicago Press, 2013. For the 'red' Atlantic see, for example, Peter Linebaugh and Marcus Rediker, The Many-Headed Hydra: Sailors, Slaves, Commoners, and the Hidden History of the Revolutionary Atlantic, London: Verso, 2000.

20 For Iberian Atlantic histories see, for example, Juan Pimentel, 'The Iberian vision: science and empire in the framework of a universal monarchy, 1500-1800', Osiris (2000) 15, pp. 17-30; Jorge Cañizares-Esguerra, How to Write the History of the New World: Histories, Epistemologies, and Identities in the EighteenthCentury Atlantic World, Stanford, CA: Stanford University Press, 2001; Antonio Barrera-Osorio, Experiencing Nature: The Spanish American Empire and the Early Scientific Revolution, Austin: University of Texas Press, 2010; Daniela Bleichmar, Paula De Vos, Kristin Huffine and Kevin Sheehan (eds.), Science in the Spanish and Portuguese Empires, 1500-1800, Stanford, CA: Stanford University Press, 2009; Neil Safier, Measuring the New World: Enlightenment Science and South America, Chicago: The University of Chicago Press, 2008; Safier, 'Global knowledge on the move: itineraries, Amerindian narratives, and deep histories of science', Isis (2010) 101, pp. 133-145; John Slater, Maríaluz López-Terrada and José PardoTomás (eds.), Medical Cultures of the Early Modern Spanish Empire, Farnham and Burlington, VT: Ashgate, 2014; Samir Boumediene, La colonisation du savoir: Une histoire des plantes médicinales du 'nouveau monde' (1492-1750), Vaulx-en-Velin: Les éditions des mondes à faire, 2016. For Arctic regions see, for example, Michael T. Bravo and Sverker Sörlin, Narrating the Arctic: A Cultural History of Nordic Scientific Practices, Sagamore Beach, MA: Science History Publications, 2002; Michael T. Bravo and Nicola Triscott (eds.), Arctic Geopolitics and Autonomy, Ostfildern: Hatje Cantz, 2011.

21 Jorge Cañizares-Esguerra, 'Some caveats about the "Atlantic" paradigm', History Compass (2003) 1, pp. 1-4; Jorge Cañizares-Esguerra and Benjamin Breen, 'Hybrid Atlantics: future directions for the history of the Atlantic world', History Compass (2013) 11, pp. 597-609. 
in danger of becoming a neo-imperial form of history; one dominated by the rise of the British Empire, and the birth of the United States'.22

The spectre of neo-imperialism within Atlantic history has offered a cautionary tale for recent conceptualizations of both Indian Ocean and Pacific Ocean historiographies. They have both pointedly eschewed the Atlantic emphasis on European exploration and colonization by emphasizing genealogies of human voyaging and migration that pre-date the colonial origins of the Atlantic world by thousands of years. ${ }^{23}$ Nevertheless, early Indian Ocean historiography sought to find narratives that unified this oceanic world in much the same way that the Mediterranean was interconnected. ${ }^{24}$ Where Michael Pearson saw littoral societies 'that have more in common with other littoral societies than they do with their inland neighbours' ${ }^{25}$ Kirti N. Chaudhuri argued for the idea of a unified Indian Ocean world on the basis of trade routes connecting the maritime world to the overland Silk Road. ${ }^{26}$ Within these conceptualizations, the influence of Islam was at least as important as European colonization, or even more so. ${ }^{27}$ Yet more recently, this search for a unified Indian Ocean has given way to plural ideas of Indian Ocean worlds. ${ }^{28}$ Sugata Bose argues that the Indian Ocean is an 'interregional arena' and encourages us to imagine 'a hundred horizons, not one, of many hues and colours' ${ }^{29} \mathrm{~W}$ ithin this pluralized Indian Ocean, Arabic traders and Islamic missionaries, South Asian mariners and East African merchants, the Hadhrami and the Armenian diaspora, and the Chinese tribute missions of Zheng He and Portuguese and Dutch colonizers all figure in a complex web of connections guided by the monsoonal nature of the ocean. ${ }^{30}$ While these historiographies emphasize connection and movement, the teleological narratives of civilizational advancement generated by Europeans are minimized within this conceptualization of oceanic space.

Pacific history has taken a similar trajectory. Heavily influenced by postcolonialism, the field seeks to elevate indigenous histories and genealogies in opposition to colonialist portrayals of the region as primitive and isolated. The central role of Pacific Islanders in defining the field has been particularly important in this regard. As Epeli Hau'ofa famously argued, European conceptions of the Pacific and its inhabitants served to entrench colonial and racist boundaries between different parts of the Pacific. ${ }^{31}$ Pacific history thus finds unity in a collective project to resurrect indigenous history, culture and

22 McDonnell op. cit. (15), p. 51. Michael A. McDonnell, 'Facing empire: indigenous histories in comparative perspective', in Kate Fullagar (ed.), The Atlantic World in the Antipodes: Effects and Transformations since the Eighteenth Century, Newcastle: Cambridge Scholars Publishing, 2012, pp. 220-236, 229.

23 Pearson, op. cit. (13), p. 3.

24 Michael Mollat, 'The importance of maritime traffic to cultural contacts in the Indian Ocean', Diogenes (1980) 28, pp. 1-18.

25 Michael N. Pearson, 'Littoral society: the concept and the problems', Journal of World History (2006) 1, pp. 353-373, 353.

26 Chaudhuri, op. cit. (13).

27 Chaudhuri, op. cit. (13), pp. 3-4. Abdul Sheriff, 'Introduction', in Sheriff, op. cit. (13), pp. 11-32, 2.

28 Sujit Sivasundaram, 'The Indian Ocean', in Armitage, Bashford and Sivasundaram, op. cit. (11), pp. 31-61.

29 Bose, op. cit. (13), pp. 4-6.

30 Bose, op. cit. (13); Ho, op. cit. (13); Abdul Sheriff, 'Globalisation with a difference: an overview', in Sheriff, op. cit. (13), pp. 11-41; Alpers, op. cit. (13); Sivasundaram, op. cit. (28).

31 Epeli Hau'ofa, 'Our sea of islands', Contemporary Pacific (1994) 6, pp. 147-161. 
knowledge. In rejecting centralizing narratives, the field necessarily draws on a much more varied and atypical source base than do other historiographies. As Damon Salesa has noted, while archaeology and ethnography provide evidence for the durability of cultures across millennia, Pacific scholars also argue that less rigid ways of knowing and recounting history are just as valid. These include oral history, genealogies and cosmologies. The blurred lines between mythological and cosmological knowledge and historical knowledge are not seen as a problem, but rather a way of recovering lost indigenous experiences of the past. ${ }^{32}$ Additionally, Pacific historians prefer to emphasize a long history of human migration that facilitated a shared culture across the region seen through the spread of Lapita pottery, as well as shared maritime technologies. ${ }^{33}$ While the Europeans who ventured into the Pacific in the sixteenth century found 'islands in a far sea', Pacific islanders have always seen 'a sea of islands'. ${ }^{34}$ Nonetheless, the gulf between these two conceptualizations of the Pacific has had a lasting impact on the region, where history itself has become the major battleground.

What, then, do these two historiographies offer to the history of science? By rejecting teleologies and recovering indigenous and non-European histories of migration and cultural production, in the Indo-Pacific historians of science can find opportunities to embrace new, pluralized methodologies. These methodologies de-emphasize the dominance of European traditions and incorporate pluralities of culture and ways of knowing. Essential to this is an uncovering of the 'middle ground' and the cultural brokers that facilitated the exchange of knowledge. ${ }^{35}$ The magnitude and variety of the waves of migration which criss-crossed the Indian and the Pacific Oceans make them some of the richest environments for investigations of cross-cultural knowledge production.

\section{Indo-Pacific methodologies and histories of science}

Of the two oceans under consideration here, the Pacific has been seen as particularly important to the development of scientific thought and methods over the course of the eighteenth and nineteenth centuries and, consequently, as 'central [to] the key debates that transformed perceptions of the very shape of human development and universal history'. ${ }^{36}$ Both in historiographical and source material, the Pacific has often been understood as a 'theatre' for Europeans to understand themselves and develop theories

32 Damon Salesa, 'The Pacific in Indigenous time', in Armitage and Bashford, op. cit. (13), pp. 31-52; Hau'ofa, op. cit. (31), p. 152.

33 Matsuda, op. cit. (4), pp. 9-22.

34 Hau'ofa, op. cit. (31), pp. 152-153.

35 For 'middle grounds', go-betweens and cultural brokers see Schaffer et al., op. cit. (6); White, op. cit. (8); Yanna Yannakakis, The Art of Being in Between: Native Intermediaries, Indian Identity, and Local Rule in Colonial Oaxaca, Durham, NC: Duke University Press, 2008; Alida C. Metcalf, Go-Betweens and the Colonization of Brazil, 1500-1600, Austin: University of Texas Press, 2005. For a Pacific point of view see Bronwen Douglas, 'Agency, affect, and local knowledge in the exploration of Oceania', in Shino Konishi, Maria Nugent and Tiffany Shellam (eds.), Indigenous Intermediaries: New Perspectives on Exploration Archives, Canberra: ANU Press, 2015, pp. 103-130.

36 Tony Ballantyne, 'Introduction', in Ballantyne (ed.), Science, Empire and the European Exploration of the Pacific, Aldershot: Ashgate Publishing Limited, 2004, pp. xv-xxxv, xv. 
of civilizational advancement. ${ }^{37}$ This ocean was the staging ground for scientific expeditions of the nascent Western powers, which defined the debates over its nature and its inhabitants for centuries to come. ${ }^{38}$ Pacific islands also inspired the theories of evolution of Charles Darwin and Alfred Russel Wallace, and saw the development and implementation of associated racial classifications. This region has thus been a continuous subject of interest to historians of science and the central locus of works on histories of imperial science evolution and biogeography, especially with regard to the function of insularity. ${ }^{39}$

When seeking a suitable example to illustrate his paradigmatic model for scientific practice, Bruno Latour naturally turned to an episode from one of the European expeditions into the Pacific. ${ }^{40}$ In 1787, as part of his mission to map the ocean, the French navigator Jean François de Galaup, Comte de La Pérouse, landed on the island of Sakhalin. In an encounter with the local inhabitants, he extracted information about the island's geography and submitted it to the imperial centre in Paris. This is where knowledge was accumulated and where his report was translated into a chart in the language of European cartography. Fixed in the form of 'immutable mobiles', this chart could now easily travel and, although initially ignorant, the European state and its agents gained possession of a tool of power and surveillance. Here, Latour is concerned with what is distinctive about modern science, illustrating how cycles of knowledge accumulation in centres of calculation contributed to the imposition of Western intellectual dominion on other cultures. ${ }^{41}$ Although of some application in the high imperial period, Latour's model has drawn extensive critique, particularly for its negligence of

37 Greg Dening, Islands and Beaches: Discourses on a Silent Land, Marquesas, 1774-1880, Honolulu: University of Hawaii Press, 1980; Marshall Sahlins, 'Cosmologies of capitalism: the trans-Pacific sector of "the world system", in Nicholas B. Dirks, Geoff Eley and Sherry B. Ortner (eds.), Culture/Power/History: A Reader in Contemporary Social Theory, Princeton, NJ: Princeton University Press, 1994, pp. 412-455.

38 Most prominent were the British voyages of James Cook, Joseph Banks and the Challenger; the French expeditions of Louis Antoine de Bougainville and Jean François de Galaup, Comte de La Pérouse; and the explorations of Vitus Bering, Alessandro Malaspina and Charles Wilkes in the services of Russia, Spain and the United States respectively.

39 See, for example, Janet Browne, The Secular Ark: Studies in the History of Biogeography, New Haven, CT: Yale University Press, 1984; Gillian Beer, 'Can the Native return?', in Beer, Open Fields: Science in Cultural Encounter, Oxford: Oxford University Press, 1996, pp. 31-54; Jonathan Hodge, 'Darwin, the Galápagos and his changing thoughts about species origins: 1835-1837', Proceedings of the California Academy of Sciences (2010) 61, pp. 89-106; David Quammen, The Song of the Dodo: Island Biogeography in an Age of Extinctions, New York: Random House, 2012; James T. Costa, Wallace, Darwin, and the Origin of the Species, Cambridge, MA: Harvard University Press, 2014; Iain McCalman, The Reef: A Passionate History: The Great Barrier Reef from Captain Cook to Climate Change, Basingstoke: Palgrave Macmillan, 2014; Alistair Sponsel, 'From Cook to Cousteau: the many lives of coral reefs', in John Gillis and Franziska Torma (eds.), Fluid Frontiers: Exploring Oceans, Islands, and Coastal Environments, Cambridge: White Horse Press, 2015, pp. 139-161; Alistair Sponsel, 'Pacific islands and the problem of theorizing: the U.S. exploring expedition from fieldwork to publication', in Katharine Anderson and Helen M. Rozwadowski (eds.), Soundings and Crossings: Doing Science at Sea, 1800-1970, Sagamore Beach, MA: Science History Publications, 2016, pp. 79-112.

40 Bruno Latour, Science in Action: How to Follow Scientists and Engineers through Society, Cambridge, MA: Harvard University Press, 1987, pp. 215-258.

41 See also James McClellan and François Regourd, The Colonial Machine: French Science and Overseas Expansion in the Old Regime, Turnhout: Brepols, 2011. 
local agency, its hierarchization of centres and peripheries, and the immutability characterizing his 'mobiles'. In this respect, Michael Bravo's and Julie Cruikshank's takes on La Pérouse's interactions with the Ainu and the Tlingit people, respectively, present an excellent response to Latour's telescopic view through the metropolitan lens. ${ }^{42}$ In paying close attention to the dynamics of a series of encounters in the field, they underscore the mutuality of the confrontation and highlight that local knowledge - both oral and ethnographic - presented essential input for the generation and deployment of 'mobiles', which were negotiated in diverse and complex cross-cultural situations.

Along with the works of scholars like Greg Dening, Nicholas Thomas and Sujit Sivasundaram, Bravo and Cruikshank present examples of nuanced consideration of Indo-Pacific cross-cultural encounters with which historians of science can productively engage. These authors highlight the contributions and practices of actors from across the wider social spectrum and, especially, the interacting roles of indigenous agents and different knowledge systems beyond European institutions. Sivasundaram has warned against portrayals that assume that 'science is a bundle of things or practices which comes fully formed or with great intentional force to intrude into the Pacific periphery' and 'could lead at times to the assumption that this maritime world was inert, sterile or controlled, like everything in a scientific work station'. ${ }^{43}$ Such depictions suggest that science was something that was done to people and the environment, rather than something which evolved and adapted in response to the environments, peoples and existing knowledge systems of a complex 'sea of islands'.

Bringing to the forefront both violent clashes and constructive dialogues, the IndoPacific thus affords historians of science the opportunity to move beyond European scientific interests to uncover the agency of local and non-elite actors. This is both in terms of other great 'civilizational' currents - emanating from Islamic, Arabic, Chinese and Indian traditions, for example - and in terms of more localized, indigenous knowledge systems that have often been considered antithetical to rigid European notions of what constitutes science. Yet this in itself requires a considerable degree of flexibility. Engseng Ho points out that an emphasis on the European presence within the Indian Ocean is largely a product of the archives that these state-sponsored projects of imperialism created: 'The difference between the English and the Indians in leaving textual tracks has nothing to do with civilization or literacy. There were reasons for writing things down and for not doing so. As well, the gnawing criticism of termites played its part'. ${ }^{44}$ The efforts of Indo-Pacific scholars to move beyond traditional archives and incorporate new source bases and methodologies are proving valuable for a new

42 Michael Bravo, 'Ethnographic navigation and the geographical gift', in David N. Livingstone and Charles W.J. Withers (eds.), Geography and Enlightenment, Chicago: The University of Chicago Press, 1999, pp. 199-235; Julie Cruikshank, Do Glaciers Listen? Local Knowledge, Colonial Encounters, and Social Imagination, Vancouver: UBC Press, 2014, esp. chapter 4.

43 Sivasundaram, op. cit. (28), p. 237. See also McDonnell, op. cit. (15), pp. 220-221.

44 Ho, op. cit. (13), p. xxiii. James Scott has recently made a very similar point, arguing that historical records preference state-based societies, since the bureaucratic apparatus of states requires the keeping of records. See James C. Scott, Against the Grain: A Deep History of the Earliest States, New Haven, CT: Yale University Press, 2017. 
generation of historians of science. Sivasundaram, for example, has called for a 'crosscontextualisation' of archives, arguing that 'by stretching the category of science across cultural perspectives and across different genres of recording and thinking, it is possible to appreciate the distinctive features of the history of science in the Pacific, and to take indigenous knowledges seriously'. ${ }^{45}$ Alongside oral histories, material culture presents a rich source of historical evidence, providing extensive insights into cross-cultural encounters and overcoming rigid binaries between European and indigenous perspectives. ${ }^{46}$ Such non-traditional archives promise to reveal clues about local informants and systems of knowledge absent from traditional archival sources.

In this issue, Genie Yoo illustrates the role that cultural go-betweens played in the creation of European knowledge in the works of Georg Everhard Rumphius (1627-1702). In tracing Rumphius's encounters with local informants from the ranks of Muslim elites and itinerant merchants, who held specialized knowledge of local plants, Yoo provides us with a unique insight into the knowledge networks at play within the early modern Maluku islands. This affirms Sivasundaram's argument that scientific theories and methods were shaped by the environment, geography, geology and physics of the oceans. ${ }^{47}$ In his article on meteorology, Martin Mahony similarly demonstrates the power of the physical environment in his examination of meteorological experimentation on the island of Mauritius in the late nineteenth century. By detailing the methods used by members of the Meteorological Society in Mauritius - both onshore and offshore - Martin reinserts the Indian Ocean into the larger story of weather observation and the development of cyclonic warning systems.

Elsewhere, contributors demonstrate the limitations and fallibility of European knowledge and methods. Katherine Parker describes how the cartographic production of knowledge in the eighteenth century did not necessarily follow rigid methodologies. Through uncovering the fictitious Pepys Island - situated in the Atlantic Ocean but long proposed by British explorers as a potential staging ground for expansion into the Pacific - Parker demonstrates that cartography was often as much the product of the aspirations and financial and practical constraints of book publishers in London as it was an engagement with navigational charts. In a different vein, Dorit Brixius shows the fallibility of European horticultural knowledge through her exploration of an attempt to transplant nutmeg from the Maluku islands to Isle de France in the mid-eighteenth century. Without the input of Malukan knowledge, these experiments were largely a failure. Brixius argues that a creolization of knowledge had to occur wherein Malukan knowledge was integrated into local horticultural practices in Isle de France, including those developed by the island's slave population.

As should be evident by now, the diverse topics of these contributions do not attempt to conceptualize a connected Indo-Pacific world. Rather, they adopt the tool of the Indo-

45 Sujit Sivasundaram, 'Science', in Armitage and Bashford, op. cit. (13), pp. 237-260, 239. See also Sivasundaram, op. cit. (6).

46 Greg Dening, Performances, Melbourne: Melbourne University Press, 1996; Nicholas Thomas, Entangled Objects: Exchange, Material Culture and Colonialism in the Pacific, Cambridge, MA and London: Harvard University Press, 1991; Neil Safier, 'Masked observers and mask collectors: entangled visions from the eighteenth-century Amazon', Colonial Latin American Review (2017) 26, pp. 104-130.

47 Sivasundaram, op. cit. (28), pp. 237-262. 
Pacific to 'provincialize Europe', to use Dipesh Chakrabarty's term. ${ }^{48}$ This is an important point to make, since, as Michael McDonnell has recently argued, the turn towards ever-expanding frameworks of transnational and global history seems to 'inevitably push us farther and farther away from indigenous peoples' ${ }^{49}$ Instead of ever more sophisticated conceptualizations of interconnected global spaces, McDonnell encourages historians to think more carefully about comparisons across geographic spaces and look towards concepts that help us bridge imposed structural divides. Matt Matsuda has proposed the use of the term 'trans-localism' for histories of different places that are nonetheless connected by their relation to the sea. ${ }^{50}$ Similarly, in critiquing the fragmentation of South East Asian history, Barbara Andaya has argued that 'the "transocean" standpoint may enable us not merely to work with a larger canvas, but to capture something of the human encounters that underwrite the communication between areas and between peoples'..$^{51}$

Geoff Bil's contribution to this issue responds to these arguments by comparing indigenous plant names as used by Alexander von Humboldt in Latin America to the later adoption of indigenous nomenclature by anthropologists in New Zealand. Importantly, Bil argues that by studying European treatment of indigenous plant names, we can also unpick leading racial theories. While the anthropologists operating in New Zealand had a greater understanding of Māori culture and language, they nonetheless utilized this knowledge to develop theories of racial primitivism and cultural degradation and decline. This indicates that the European adoption of native knowledge systems was by no means a neutral undertaking - a point also raised by Bronwen Douglas. ${ }^{52}$ In assembling the worlds of the Indo-Pacific from the multiple experiences of the people involved, knowledge production and mobilization reflect the interactions, conflicts and collaborations between different agents from different places and cultural traditions.

\section{Island spaces in the Indo-Pacific}

It is now commonly accepted that all science is situated. ${ }^{53}$ Considering the spatiality of islands enables us to engage with key topics in the history of science, including those of

48 Dipesh Chakrabarty, Provincializing Europe: Postcolonial Thought and Historical Difference, Princeton, NJ: Princeton University Press, 2000.

49 McDonnell, op. cit. (15), p. 225. For issues with the concept 'transnational', which is inevitably hiding inside the restrictive and often anachronistic concept of 'nation', see Christopher A. Bayly, Sven Beckert, Matthew Connelly, Isabel Hofmeyr, Wendy Kozol and Patricia Seed, 'American Historical Review conversation: on transnational history', American Historical Review (2006) 111, pp. 1441-1464.

50 Matsuda, op. cit. (4), pp. 5-6.

51 Barbara Watson Andaya, 'Oceans unbounded: transversing Asia across "area studies"', Asia-Pacific Journal (2007) 5, pp. 669-690, 15.

52 Bronwen Douglas, Science, Voyages, and Encounters in Oceania, 1511-1850, New York: Palgrave Macmillan, 2014.

53 For the 'spatial turn' in history of science see, for example, Livingstone, op. cit. (6); Diarmid A. Finnegan, 'The spatial turn: geographical approaches in the history of science', Journal of the History of Biology (2008) 41, pp. 369-388. 
globality and locality, the centre-periphery hierarchy, and cross-cultural knowledge production. Islands possess the advantage of providing insights into global interactions without losing grasp of localized processes themselves. Viewed as a series of microcosms, they provide opportunities for considerations of knowledge production and exchange in systems with multiple centres. ${ }^{54}$ The sites of the islands of the Indo-Pacific are thus particularly well suited to decentring European narratives of science and, in bringing to attention localized kinds of agency, promise a more nuanced view of the plurality of knowledge traditions and agents involved in the emergence of science and modernity. This special issue seeks to explore what happens to knowledge in these spaces: how island environments have shaped scientific practices and how, in turn, these practices have contributed to the 'making' of islands as intensive sites of cultural exchange, colonialism and globalization.

As both physical and imaginary sites, islands played a central role in the formation of empires as well as their eventual dismantling. ${ }^{55}$ They were some of the first landfalls and navigational points of reference in early European forays overseas, and later some of the first colonies. They are places that witnessed the impact of advancing colonialism and globalism and, therefore, offer rich sources of comparative material for historians of science and empire. Just as significantly, the imperial spaces of islands also inspired European imaginations. In early colonial discourse, islands were the subject of Edenic projections. Francis Bacon, for example, imagined a seventeenth-century utopia on the fictional island of New Atlantis inspired by the recent uncovering of the Pacific Ocean. This was an idealized view of the Pacific that continued to be reflected more than two centuries later in the primitivist artwork of Paul Gauguin. ${ }^{56}$ Yet such fantasies of paradise were rarely met by reality. While islands offered respite for voyagers, they also signalled the threat of shipwreck, which became a reality for many Spanish galleons off the coast of Guam in the seventeenth century. ${ }^{57}$ Furthermore, prominently featuring within European imaginations was the view of islands as both scientific and social laboratories. ${ }^{58}$ Constituted as such, islands have been the locations of novel experiments

54 See, for example, Jonardon Ganeri, 'Well-ordered science and Indian epistemic cultures: toward a polycentered history of science', Isis (2013) 104, pp. 348-359; Pedro Cardim, Tamar Herzog, José Javier Ruiz Ibáñez and Gaetano Sabatini (eds), Polycentric Monarchies: How Did Early Modern Spain and Portugal Achieve and Maintain a Global Hegemony?, Eastbourne: Sussex Academic Press, 2014.

55 See, for example, Richard H. Grove, Green Imperialism: Colonial Expansion, Tropical Island Edens and the Origins of Environmentalism, 1600-1860, Cambridge: Cambridge University Press, 1995; Sujit Sivasundaram, Islanded: Britain, Sri Lanka, and the Bounds of an Indian Ocean Colony, Chicago: The University of Chicago Press, 2013.

56 Francis Bacon, New Atlantis (ed. G.C. Moore Smith), Cambridge: At the University Press, 1900; first published 1628. Paul Gauguin, Noa Noa: The Tahiti Journal of Paul Gauguin (tr. O. F. Theis), New York: Dover Publications, 1985. See also Anne Salmond, Aphrodite's Island: The European Discovery of Tahiti, Berkeley: University of California Press, 2010.

57 Schurz, op. cit. (14), pp. 255-259; Juan Pobre de Zamora, Historia de la Pérdida y Descubrimiento del Galeón 'San Felipe' (ed. Jesús Martínez Pérez), Ávila: Institución 'Gran Duque de Alba' de la Diputación Provincial de Ávila, 1997; Stephanie Mawson, 'Rebellion and mutiny in the Mariana islands, 1680-1690', Journal of Pacific History (2015) 50, pp. 133, 146-147.

58 On islands as laboratories of science see, for example, Sebastiao Nuno Silva, 'The land of flies, children and devils: the sleeping sickness epidemic in the island of Príncipe (1870s-1914)', PhD thesis, Oxford 


\section{4}

Sebestian Kroupa, Stephanie J. Mawson and Dorit Brixius

in control, surveillance and incarceration, as recent work on a multitude of 'carceral archipelagos' has demonstrated. ${ }^{59}$ In their bid to systematize, control and exploit island environments, different authorities sought to implement structures that were tailored to specific, local requirements. Yet utopian visions of islands as spaces to be experimented on, or shaped according to imperial visions, were disrupted and defined by local realities. The delicate equilibria of island environments could alter the outcomes of these experiments, as could the forces of extrinsic agents arriving on the tides of the oceans. Martin Mahony's paper addresses these issues in detail. As he argues, 'Ocean "cyclonology" offers an opportunity to reflect on how the physical, economic and cultural geographies of an island colony combined to produce spaces of weather observation defined by both connection and disconnection, the latter to be overcome not only by infrastructure, but also by the imagination'.

Although colonial projects cannot be fully understood without considering the visions of metropolitan agents, ${ }^{60}$ the transformations and experiments that islands were subjected to were codirected by islanders themselves. Slave revolts and indigenous power presented persistent challenges to imperial rule and, particularly at times of wars and revolutions, island societies functioned as a mirror and a magnifying glass of wider global disputes and trends. Reconstructing these histories from below provides insights into how metropolitan visions played out on the ground, as well as into the contributions of non-European and non-elite agents, who were caught up amid the surging forces of colonialism and globalism whilst seeking to resist, exploit or manage them. Genie Yoo's article, while nominally about colonial botanical knowledge, uncovers the story of magic rings used by islanders in the Indonesian archipelago as talismans. These rings became powerful symbols within resistance movements against both European and local imperialisms - a story which she explores through a rebellion led by Trunajaya on the island of Java in the 1670s.

As sites of cross-cultural encounters, islands promise especially valuable insights into questions of knowledge entanglements. As fragments amidst waters, islands are at once discrete entities and parts of a larger block, from which they are in exile and to which they are related. As such, they epitomize the perpetual oscillations between the

University, 2014; Adrian Young, 'Mutiny's bounty: Pitcairn Islanders and the making of a natural laboratory on the edge of Britain's Pacific empire', PhD thesis, Princeton University, 2016. Recent studies of the Galápagos Islands reveal that the visions of 'natural laboratories' have endured and shaped modern discourse surrounding the archipelago, including policies on tourism and conservation. However, as their authors point out, these ideas and discussions commonly differ from and fail to take into consideration local voices and views. See, for example, Diego Quiroga, 'Crafting nature: the Galapagos and the making and unmaking of a "natural laboratory", Journal of Political Ecology (2009) 16, pp. 123-140; Elizabeth Hennessy and Amy L. McCleary, 'Nature's Eden? The production and effects of "pristine” nature in the Galápagos islands', Island Studies Journal (2011) 6, pp. 131-156.

59 Clare Anderson (ed.), A Global History of Convicts and Penal Colonies, London: Bloomsbury Academic, 2018; Anderson, 'Transnational histories of penal transportation: punishment, labour and governance in the British imperial world, 1788-1939', Australian Historical Studies (2016) 47, pp. 381-397; Anderson, 'Subaltern lives: history, identity and memory in the Indian Ocean world', History Compass (2013) 11, pp. 503-507.

60 Sarah Easterby-Smith and Emily Senior, 'The cultural production of natural knowledge: contexts, terms, themes', Journal for Eighteenth-Century Studies (2013) 36, pp. 471-476. 
notions of fixed and relational character, inherent to the processes in which new forms of knowledge and identities emerge during cross-cultural encounters. In other words, islands provide insights into both roots and routes, but at the same time into rootlessness, perhaps most severely expressed in terms of forced migrations. ${ }^{61}$ In these culturally rich and contested spaces, different groups, free or enslaved, sought to create distinct identities for themselves and forge their fortunes. Knowledge was intricately tied to these developments. As Europeans sought the assistance of indigenous people and slaves due to their expertise in local environments, transfers of skills and techniques went hand in hand with - and often dictated - movements of people. ${ }^{62}$ Dorit Brixius's contribution particularly underscores this point, as she uncovers the role of both islanders and slaves in colonial horticultural experiments in eighteenth-century Isle de France. The same knowledge which made these communities useful in the eyes of the invaders, however, could present a means of resistance. For instance, throughout the early modern period, locals and slaves were sought for information about useful plants but feared for their knowledge of poisons and potions. ${ }^{63}$ Genie Yoo similarly shows how local beliefs had powerful resonance during moments of rebellion. Knowledge was a key element around which island communities constructed their identities, and determined the ways in which they were perceived by outsiders.

In bringing to the fore the agency of local peoples, islands emerge as environments where cultures were clashing and blending, where identities were in a state of flux, and where new traditions were forged and old ones reshaped. The heavily theorized and much-debated concept of hybridity deserves a brief commentary here. Overlapping with a plethora of terms such as creolization, mestizaje, coproduction, coconstruction or circulation, these notions have recently come under fire for suggesting a false idea of coherence, partnership and connectedness, which does not do justice to the fragmentary, multivalent and often violent and short-lived interactions. ${ }^{64}$ While the frequent dichotomization between European and indigenous knowledge tends to distort cross-cultural interactions into encounters between opposed, homogeneous categories, hybridity has at times led to a sense that conquered peoples were gradually 'westernized'

61 Godfrey Baldacchino, The Political Economy of Divided Islands: Unified Geographies, Multiple Polities, Basingstoke and New York: Palgrave Macmillan, 2013.

62 See, for example, Carney, op. cit. (19); Virginia Bernhard, Slaves and Slaveholders in Bermuda, 16161782, Columbia: University of Missouri Press, 1999; Gwyn Campbell, 'Introduction: slavery and other forms of unfree labour in the Indian Ocean world', Slavery o Abolition (2003) 24, pp. ix-xxxii; Virginia Bernhard, A Tale of Two Colonies: What Really Happened in Virginia and Bermuda?, Columbia and London: University of Missouri Press, 2011; James E. Newton and Ronald L. Lewis, The Other Slaves: Mechanics, Artisans, and Craftsmen, Boston, MA: G.K. Hall, 1978.

63 Carney, op. cit. (19); Londa L. Schiebinger, Secret Cures of Slaves: People, Plants, and Medicine in the Eighteenth-Century Atlantic World, Stanford, CA: Stanford University Press, 2017; Karol K. Weaver, Medical Revolutionaries: The Enslaved Healers of Eighteenth-Century Saint Domingue, Urbana and Chicago: University of Illinois Press, 2006; Gwendolyn Midlo Hall, Africans in Colonial Louisiana: The Development of Afro-Creole Culture in the Eighteenth Century, Baton Rouge: Louisiana State University Press, 1992.

64 See, for example, Gómez, op. cit. (19); Megan Vaughan, Creating the Creole Island: Slavery in Eighteenth-Century Mauritius, Durham, NC: Duke University Press, 2005; Anna Winterbottom, Hybrid Knowledge in the Early East India Company World, Basingstoke: Palgrave Macmillan, 2016. 
and that local communities lacked agency within this process. Moreover, the terms 'hybrid' and mestizo were originally associated with animal reproduction and, alongside criollo, appropriated in colonial contexts in European politics of ethnic hierarchization and segregation.

By the same token, the concept of hybridity has been critiqued for its holistic, essentialist and static view of culture: a hybrid is always a product of the fusion of two entities, failing thus to account for cultural dynamism. Drawing on Nicholas Thomas's Entangled Objects (1991), the recent special issue edited by Ralph Bauer and Marcy Norton suggests using the term 'entanglements', which emphasizes continuous and unresolved processes rather than the unilateral impact of one culture upon another, and attends to the array of sources, agencies, directions of influence and modalities of cross-cultural interactions. ${ }^{65}$ Unrestricted to a particular time or place, entanglements enable one to focus on single or multiple sites of historical transformation, problematizing concepts such as contact zones, borderlands and peripheries. This special issue endorses the concept of entanglement, which recognizes that local actors regularly functioned as participants in the knowledge and identities that they created, the complex and multifaceted nature of which cannot be reduced to models of resistance or cooperation alone.

By seeking to overcome artificial frontiers and reveal the forces which tied or divided the spaces concerned, this issue pays close attention to the complex networks of local patronage and to the agency of local actors. Within these networks, European learned men feature side by side with figures of non-European and non-privileged background - servants, women, artisans - and only through recognition of their role in these interactions can we paint a more complete picture of the Indo-Pacific. Travellers and islanders entered and left, met and mixed, and with them travelled myriad of ideas and practices across a diversity of traditions. Nonetheless, it would be a mistake to view the Indo-Pacific as an idyllic, free-flowing and boundless world. Much of the movement was tied to expansion and warfare, the lives of migrants were above all defined by violence and dislocation, and encounters were marked by exercises of power and coercion. Disconnections and boundaries are central to conceptualizing any kind of space, since a field that tries to encompass everything ultimately achieves nothing. As Braudel wrote for the Mediterranean, 'We should imagine a hundred frontiers, not one; some political, some economic, and some cultural'. ${ }^{66}$ Similarly, the Indo-Pacific encompasses a plurality of different worlds, tied together by webs of connections, but at times frayed by flexible boundaries, both internal and external. The key task in integrating the Indian and the Pacific Oceans is to bring to life these horizons and pluralize the spaces in which knowledge travelled at specific times but not at others. This special issue

65 Ralph Bauer and Marcy Norton, 'Introduction: entangled trajectories: Indigenous and European histories', Colonial Latin American Review (2017) 26, pp. 1-17. As Karen Graubart put it, 'Rather than name an outcome, entanglement suggests ongoing confrontations, shifts, and revisions: a state of mutual learning and pushback which does not dissolve into a final product'. Karen B. Graubart, 'Shifting landscapes: heterogeneous conceptions of land use and tenure in the Lima valley', Colonial Latin American Review 26 (2017), pp. 62-84.

66 Braudel, op. cit. (7), p. 171. See also Bose, op. cit. (13). 
seeks to understand how Indo-Pacific worlds became connected and disconnected, bearing in mind that strong claims of connectedness can only be built by rigorous scholarly analysis situating particular sites both in their local contexts and in the wider seascape.

\section{New horizons}

The contributions to this issue suggest new approaches to science and knowledge production in the Indo-Pacific. While our contributors have all risen to the task of 'provincializing Europe' by examining the fallibility of European scientific methods and the importance of indigenous and islander systems of knowledge, their contributions nonetheless use Europeans as their entry point into their topics of examination. The future of the field rests not only on uncovering scientific 'middle grounds' and the cultural brokers that allowed Europeans access to native knowledge, but also on the pluralizing of the very notions of science and knowledge themselves. While Engseng Ho's point about the tyranny of European state archives remains salient, it should be read as a clarion call for future researchers to think innovatively about archives and explore other sources of historical evidence, including oral histories and material culture. For instance, recent investigations into Australian Aboriginal communities have shown that oral history has accurately recorded memories of significant climatic events, including the inundation of Australia's coastline more than seven thousand years ago. Such research demonstrates the potential of oral history as a source of wide-reaching environmental and historical knowledge. ${ }^{67}$

Moving beyond Eurocentric notions of islands, we believe that these spaces continue to hold great potential for historians of science as sites of hybridity and exchange. Looking to the future, islands are set to become models for novel technologies within an increasingly digitized world. In our age, when people are increasingly connected virtually rather than territorially, the metaphor of islands has ceased to be associated exclusively with aquatic spaces as the entire globe has become archipelagic. Neither have islands lost their utopian and dystopian qualities. The recent emergence of the concept of 'seasteading' - a hybrid of homesteading and the sea - marks a new era of libertarian utopian thinking, in which proponents advocate the creation of new model societies on constructed, floating islands at sea. These self-sufficient resorts for the ultra-rich are designed to operate outside the confines of states, laws and taxation systems. ${ }^{68}$ Although recent attempts to establish such a utopian experiment have failed, ${ }^{69}$ islands remain sites of real dystopia, as epitomized by the Australian government's brutal

67 Patrick D. Nunn and Nicholas J. Reid, 'Aboriginal memories of inundation of the Australian coast dating from more than 7000 years ago', Australian Geographer (2016) 47, pp. 11-47.

68 Philip E. Steinberg, Lizabeth Nyman and Mauro J. Caraccioli, 'Atlas swam: freedom, capital, and floating sovereignties in the seasteading vision', Antipode (2012) 44, pp. 1532-1550

69 Melia Robinson, 'A Silicon Valley billionaire's dream of a gloating libertarian utopia may have finally been killed', Business Insider, 8 March 2018, at http://uk.businessinsider.com/libertarian-peter-thiel-utopiaseasteading-institute-2018-3/\#in-a-2009-essay-thiel-wrote-between-cyberspace-and-outer-space-lies-the-possibilityof-settling-the-oceans-1, accessed 6 September 2018. 
offshore mandatory detention regime for asylum seekers. ${ }^{70}$ Yet even here, cycles of resistance and agency continue, poignantly depicted in Behrouz Boochani's 'poet's manifesto' penned in honour of the refugee resistance that took place on Manus Island last year: 'Our resistance is the spirit that haunts Australia. Our resistance is a new manifesto for humanity and love'. ${ }^{71}$

At the same time, modernization and globalization have produced a new threat in the shape of climate change, posing one of the most critical challenges to humankind. Islands have acquired a new significance as their worlds are threatened with disappearance. As sea levels continue to rise, it is now or never for islanders and their homes. This makes island-centred and islander-generated histories of the Indo-Pacific more important than ever. Above all, historians of science need to include the thoughts, voices and ideas of islanders themselves in order to understand the historical, as well as contemporary, dimensions of islands. Our perceptions of what islands can represent have already been greatly expanded by drawing on indigenous epistemologies and, given the unique spatial characteristics of islands, their multiple meanings and functions cannot be grasped unless explored in situ. It is high time to expand beyond our own metaphorical islands and cross the beaches circumscribing these worlds in search of a closer dialogue.

70 Amnesty International, 'Punishment not protection: Australia's treatment of refugees and asylum seekers in Papua New Guinea' (report, 2018), at www.amnesty.org/download/Documents/ASA3477812018ENGLISH.pdf, accessed 6 September 2018.

71 Behrouz Boochani, 'A letter from Manus Island', Saturday Paper, 9-15 December 2017, at www. thesaturdaypaper.com.au/news/politics/2017/12/09/letter-manus-island/15127380005617, accessed 6 September 2018. 